\title{
相関離散分布流量を受ける貯水池の利水機能評価の研究 \\ STOCHASTIC EVALUATION OF THE WATER UTILITY FUNCTION OF THE RESERVOIR WITH DISCRETE CORRELATED INFLOWS
}

\author{
鈴木正 人* $^{*}$ 長尾正志** \\ By Masato SUZUKI and Masashi NAGAO
}

\begin{abstract}
This study aims at the stochastic evaluation of the water utility function of reservoir with discrete Markovian correlated inflows. Matrix algebraic analysis has been carried out with two-step transition model proposed by the authors. Some statistics have been clarified for the quantitative and sequential characters of the reservoir, for example, the passage time to the first emptiness. Taking account of various characteristics of emptiness, the analytical representation of criteria for effectiveness of water utility in the reservoir is developed, and stochastic consideration are presented. Numerical calculation is carried out for the comparison with the operation of non-prediction, ideal stochastic DP, and linear regression model with inflow information for the case of correlated Binomial inputs. It is found that linear regression model is useful according to the probabilistic judgement of vulnerability of water -shortage.

Keywords : stochastic reservoir theory, drought, two-step transition model, emptiness probability, first passage time
\end{abstract}

\section{1. 本研究の概要}

渇水期の流入量を離散モデル化して, 貯水池の利水機 能評価を行う際に, 半旬などのある程度短い単位期間を 対象とするときには，入力としての渴水時流況の代表的 な特性の 1 つである強い自己相関性を無視することはで きない.そこで本研究は, 著者らがさきに提案した 2 段 階推移モデルによる相関離散分布流量を受ける貯水池理 論1)を用いて，賍水池の利水機能評価を行ったものであ る.まず時間的評価として, 任意の貯水量状態から始まっ て貯水池が空になるまでの時間（以後空水到達時間）に 関する問題の 2 段階推移モデルによる解法を示した. ま た, 若干のケースについて数値実験解および, 従来の解 との比較を行った. 次に, 利水機能の評価の一貫として, 2 段階推移モデルによる期待放流量系列の導出方法を示 し, これら空水到達時間, 期待放流量系列, および, さ きに提示した貯水量定常分布 ${ }^{1)}$ 用いて, 利水安全度指

* 学生会員 工修 名古屋工業大学工学研究科博士後期課程 学生 (广466 名古屋市昭和区御器所町)

** 正会員 工博 名古屋工業大学教授 工学部社会開発工学 科（同上）
標との関連を考えたうえで, 利水機能評価関数を設定し た. 最後に, 無節水操作, 確率 DP 操作, 線形予測操作な どの操作方法の利水機能評価を行うことによって, 最適 操作への具体的方策の示唆を行っている.

\section{2 段階推移モデルの概要 ${ }^{1)}$}

2 段階推移モデルは，ある単位期間を対象として，ま ず貯留のみを考え, ついで期末に放流のみを行うように 考えたモデルである. 貯留可能性, 放流可能性はそれぞ れ期首, 期末という離散時点で判別される. また, すべ ての流入量, 貯水量は時間的, 量的に離散化された状態 で取り扱い, 流量時系列の自己相関性は一次マルコフと した流量の条件付き離散分布で勘案される. なお貯水池 の貯水池容量, 貯水量や放流量は, 流量の離散化単位の 整数倍で表現する.

まず貯留による推移，すなわち貯留推移は次式で表わ せる。

$$
\{H\}_{2}^{s_{2}}=\{H\}^{s_{1}} \cdot \boldsymbol{G}
$$

ここで, $\boldsymbol{G}$ は条件付き流入量分布で構成される貯留推移 確率行列である。また $\{H\}$ は貯水量分布ベクトルで,

$$
\begin{aligned}
& \{H\}=\left\{H_{0}, H_{1}, \cdots, H_{i}, \cdots, H_{K}\right\} \\
& H_{i}=\left(h_{0 i}, h_{1 i}, \cdots, h_{j i}, \cdots, h_{n i}\right)
\end{aligned}
$$


の成分から構成される. $K$ は貯水池容量， $n$ は流入量の 上限である.ここで, 要素 $h_{j i}$ は流入量 $j$ を得て貯水状態 $i$ になる確率を, 添字 $s$ は期間 $s$ を, 添字 1,2 はそれぞ れ期間の期首，期末を意味する.

次に，放流による推移，すなわち放流推移は次式のよ うに表わされる。

$\{H\}^{s+1}{ }_{1}=\{H\}^{s} \cdot \boldsymbol{R}$

ここで, $\boldsymbol{R}$ は 1 または 0 の要素から構成される放流推移 (確率) 行列である. いま, $R(i j)$ を貯水状態が $i$, 流入量 が jの場合の実放流量（目標放流量とは異なる場合もあ

る）とすると， $h_{j i 2}^{s}$ に対応する行のうち,

$i-R(i j)=L$

に対応する列, つまり $h_{j L 1}^{s+1}$ に対する列に要素 1 が, 他の 要素に 0 が入る. 放流操作（放流量）がどんなに複雑に なっても, 貯水状態 $i$, 流入量 $j$ が決まれば $R(i j)$ は一意 に決まり，その推移先 $L(=i-R(i j))$ も一意に決まるか ら, 放流推移行列 $\boldsymbol{R}$ は推移確率行列の性質をもつ.

式 (1)，（2）を合成すると，

$\{H\}^{s+1}{ }_{1}=\{H\}^{s} \cdot \boldsymbol{P}, \quad \boldsymbol{P}=\boldsymbol{G} \cdot \boldsymbol{R}$

となり, 貯水量の推移が独立な場合と同様に表記される.

\section{3. 空水到達時間の行列表示}

貯水池の利水機能を議論するうえで，興味の 1 つに時 間的な側面がある。その代表に，任意の初期貯水量を出 発点とした貯水量系列が時間の経過とともにどのような 推移を示すかという問題がある．特に問題となるのは， 初めて空水に至る到達時間の平均值や分散, またその確 率分布そのものを明らかにすることである。なお，ここ では空水状態に到達する時間として議論をしていくが, 「然水」の表現を,「利水安全度からみた危険な貯水量」 と扔きなおした理論展開も類似の形式で取り扱うことが できる.

さて，流入量に相関がない独立モデルに対する時間的 問題は, $\mathrm{Moran}^{2)}$, 長尾ら ${ }^{3)}$ により研究されているが，そ の理論は貯水量の推移確率行列の導出が基礎となってい た. 2 段階推移モデルによれば，式（3)に示したように 流入量に相関がある場合にも，眝水量の推移確率が独立 な場合と同じ形式に表現された。したがって，従属の場 合の時間的問題も若干の修正によって，同じ表現が可能 になる。

\section{（1）吸収マルコフ連鎖による空水到達期待時間に関 する統計量の導出}

眝水量状態の時間的経過を, 酔歩粒子の運動に模擬し て考之てみよう ${ }^{3)}$. 一般に貯水量推移は, 各状態が過渡的 な過程であると考えられる。つまり，貯水量が空になっ たとしても空であり続けるわけではなく，正の貯水量に
回復する可能性は残されている．しかし，初めて空にな る時間を問題にするときには，空水状態を吸収壁（空に なったら空であり続けるような境界条件）に㧍きなおし て考えることができる，なぜなら，利水安全度を問題に するような渴水期では, 空に至るまでの期間の特性が問 題であり，空になってから後の貯水量推移は，いまの場 合関心外だからである。

貯水量の推移過程を吸収壁の酔歩問題におきなおすに は, 貯水量が空水（つまり貯水状態が 0 ) の状態を吸収 状態にとればよい．２段階推移モデルでは，貯水状態が 流入量の条件付きで表現されているから，流入量の条件 にかかわらず貯水状態 0 をすへて吸収状態に採る，具体 的には, 貯水量の推移確率行列 $\boldsymbol{P}$ において, $h_{j 0}(j=0,1$, $\cdots, n)$ (流入量 $j$ を受けて貯水量が 0 となる確率) に対応 する要素部分を単位行列で置換した推移行列 $\boldsymbol{P}^{\prime}$ を用い る.すなわち， $\boldsymbol{P}^{\prime}$ は以下のように表現できる。

$$
\begin{aligned}
& \boldsymbol{P}^{\prime}={ }_{h_{j 0}}\left[\begin{array}{c:c}
h_{j 0} & h_{j i} \\
\boldsymbol{I} & \mathbf{0} \\
\hdashline \boldsymbol{T} & \boldsymbol{\Gamma}
\end{array}\right] \\
& (i=1,2, \cdots, K) \quad(j=0,1, \cdots, n)
\end{aligned}
$$

ここで $\boldsymbol{I}$ は単位行列で吸収状態に対応する。つまり空水 状態 $h_{j 0}$ は空水状態 $h_{j 0}$ にしか推移できない. また, $\boldsymbol{T}$ は 非空水状態 $h_{j i}(j=0, \cdots, n ; i=1,2, \cdots, K)$ 加空水状態 $h_{j 0}$ へ推移する領域要素を表わし, $\Gamma$ は非空水状態 $h_{j i}$ か ら非空水状態 $h_{j i}$ へと推移する過渡状態の領域要素を意 味する。なお 0 は零行列で，現実にはこのような領域状 態は存在しない。

詳しい説明は文献 ${ }^{4} に$ に譲るとして, 平均吸収時間, 吸収 確率を求める手順を示す。まず基本行列 $N$ を，I- $\Gamma$ の 逆行列として

$$
\boldsymbol{N}=(\boldsymbol{I}-\boldsymbol{\Gamma})^{-1}
$$

とする.なお, $\boldsymbol{N}$ の各要素は, 初期状態 $h_{j i}(j=0,1, \cdots, n$; $i=1,2, \cdots, K)$ から出発して, 空水状態 $h_{j 0}$ へ達するまで に, 各状態をおのおの何回経たかを示す期待值である.

ついで，空水到達時間 $t_{e}$ (平均吸収時間) の期待值べ クトル $\tau$ は, すべての要素が 1 の列べクトル $\xi$ 用い て, 次式で求められる.

$$
\tau=\boldsymbol{N} \cdot \xi \cdots
$$

同様に空水到達時間に関するさらに高次の積率や統計量 も計算できる，たとえば分散べクトルは，

$$
\operatorname{Var}\left(t_{e}\right)=(2 \boldsymbol{N}-\boldsymbol{I}) \tau-\tau_{s q}
$$

で計算できる.ただし， $\tau_{s q}$ は $\tau$ の各要素の平方を要素と する行列である。

以上の手順は, 流入量系列が独立な場合となんら相違 ない.ところで 2 段階推移法では, 貯水量推移が賍水量 
と流入量の同時生起の確率で表わされていた．他方独立 流量の場合は, 初期貯水量からの推移がただ 1 つの流量 状態の確率要素に対応していた，換言すれば，従属流量 の場合には貯水量状態が同時分布としての流大量の状態 によって細分化されていると考えればよい.したがって, 従属流量の場合の基本的な考え方は, ある初期流量（あ るいは初期貯水量）状態を前提とした推移を対象とする 場合には, 推移確率の内部での初期条件を満たす部分領 域を使う。また, 流量（あるいは貯水量）条件を特定し ない推移を対象とする場合には，先に出た結果に初期流 量（あるいは貯水量）に関する周辺分布の重みを勘案し た加重平均を用いればよい.

\section{（2）行列演算による空水到達時間の分布の導出}

貯水池の時間的問題に対する平均や分散といった統計 量を求める手段のほかに, 空水到達時間の確率分布を順 次計算していく方法がある。ここでは非空水の任意の初 期貯水量分布 $\boldsymbol{U}, \boldsymbol{U} \equiv\left\{U_{1}, U_{2}, \cdots, U_{i}, \cdots, U_{K}\right\}, U_{i} \equiv\left(u_{0 i}\right.$, $\left.u_{1 i}, \cdots, u_{n i}\right)$ から始まり空になるまでの推移を 1 ステッ プずつ求めていく.ただし， $u_{0 i}, \cdots$ は当該期間に流入量 0

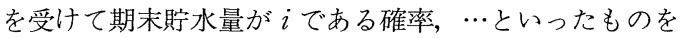
表わす.

さて, 非空水状態から空水状態への推移は, 推移行列 $\boldsymbol{P}^{\prime}$ の部分行列 $\boldsymbol{T}$ で表現されていた．したがって，1 1 ス テップで空水状態 0 に至る確率ベクトル $\boldsymbol{f}_{0}^{1}$ は, 次式のよ うに書ける。

$$
\boldsymbol{f}_{0}^{\mathrm{l}}=\boldsymbol{U} \cdot \boldsymbol{T}
$$

ここで,

$$
\boldsymbol{f}_{0}^{1} \equiv\left\{f_{00}^{1}, f_{01}^{1}, \cdots, f_{0 j}^{1}, \cdots, f_{0 n}^{1}\right\}
$$

である.たとえば, $\boldsymbol{f}_{0}^{1}$ の要素 $f_{0 j}^{1}$ は, 初期貯水量分布 $\boldsymbol{U}$ から 1 ステップで空水になる確率と流入量 $j$ との同時確 率を意味する。

次に, 2 ステップで初めて空水になる確率ベクトル $f_{0}^{2}$ は，1ステップ目で非空水状態へ推移し， 2 ステップ目 で空水状態へ推移する。 そこで, 非空水状態から非空水 状態へ推移する行列 $\Gamma$ を用いて，この確率は，

$$
f_{0}^{2}=U \cdot \Gamma \cdot T
$$

で表わされる。一般的に $N$ ステップで初めて空になる確 率べクトル $\boldsymbol{f}_{0}^{N}$ は, $N-1$ ステップで非空水状態から非空 水状態へと推移し，N ステップ目で空水状態へと推移す るから, $N \geqq 2$ として

$$
\boldsymbol{f}_{0}^{N}=\boldsymbol{U} \cdot \boldsymbol{\Gamma}^{N-1} \cdot \boldsymbol{T}
$$

と表わされる。なお，1 ステップの推移である式( 8 )の 場合でも $\Gamma^{0} \equiv I$ (単位行列) と定義しておけば，式(10)

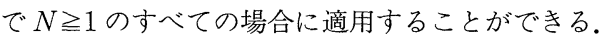

\section{（3）数值実験による空水到達期待時間の導出}

これらの計算による妥当性を検証するために，数值実 験により相関離散分布流量を受ける貯水池の空水到達期
待時間を求める. それには, 貯水池条件（有効貯水池容 量 $K$, 目標放流量 $M$ ), 流入量条件（相関二項分布の母 数である上限 $r$, 形状母数 $a$, 相関係数 $\rho)$ を設定し, 模 擬発生させた流入量系列を用いる。採用した相関二項分 布の周辺分布 $P(i)$, 条件付き分布 $P_{i j}$ を次式に示す.

$$
\begin{aligned}
& P(i) \equiv \operatorname{Pr}\left[X_{t}=i\right]=\left(\begin{array}{l}
r \\
i
\end{array}\right)(1-a)^{r-i} a^{i} \\
& P_{i j} \equiv \operatorname{Pr}\left[X_{t+1}=j \mid X_{t}=i\right] \\
& \left.=\sum_{s=0}^{\min (i, j)}\left(\begin{array}{l}
i \\
s
\end{array}\right)\left(\begin{array}{r}
-i+r \\
j-s
\end{array}\right)\{a(1-\rho)+\rho)\right\}^{s} \\
& \times\{1-a(1-\rho)\}^{s+r-i-j} a^{i-s} \\
& \times(1-a)^{i-s}(1-\rho)^{i+j-2 s} \\
& (i, j=0,1,2, \cdots, r)
\end{aligned}
$$

さて任意の初期貯水量 $u$ から貯水量推移を追跡計算 し, 空水に至るまでのステップ数を求めると, これが先 述の空水到達時間に相当するはずである.なお, Phatarfod の酔歩理論による結果と比較するために，その前提 条件である溢水せずに空になる確率5) $\left(P_{u}\right)$ も併せて求め ている。

各貯水池条件に対し, 流入量系列を 1000 個 $\times 100$ ケー ス発生させ, 各ケースの平均値を空水到達期待時間とし た。

\section{（4）適用計算および従来の方法との比較}

Phatarfod らは酔歩理論により，3 状態二項分布流量 を受ける貯水池の任意の初期貯水量から始まり溢水する ことなく空になる時間を, 母関数の形で求めている ${ }^{5)}$. ま た，長尾はそれをもとに平均值を，さらに，より一般な 二項分布入力に対する近似解およびその近似度を検討し ている6).ここでは，2段階推移法による解と, Phatarfod の解と，さらに数值実験解とを比較する.

$K=50, M=1, r=2, a=0.4, \rho=0.6$ の条件で， 2 段 階推移法と Phatarfodの方法によりそれぞれ任意の貯 水状態から空水到達期待時間を求め, Phatarfodの解を 真値とした場合の相対誤差と, 溢水せずに空になる確率 $P_{u}$ との関係を表わしたのが図一 1 である. 2 段階推移法 と Phatarfodの方法との相違は, Phatarfodの方法が, 溢水せずに空水に至るという前提での解であるのに対 し， 2 段階推移法は，何ら制約はない。溢水せずに空に なる確率が $P_{u}$ であることを考えると， $P_{u} \fallingdotseq 1$ であれば， Phatarfodの解も, 2 段階推移法による解も, 溢水しない という条件で一致し, 両者の解が合致することが推測さ れる。図をみると, $P_{u} \fallingdotseq 1$ の場合ほとんど相対誤差は 0 に なっていることからこの解釈は正しいといえよう．2段 階推移法と Phatarfodの方法は, たとえば, 初期貯水量 が十分に少ないといった，溢水しない条件のもとでは， どちらの方法を用いてもよいと思われる.しかし， $P_{u}$ が 小さくなるに従って誤差は大きくなり，最大 0.8 にもな 


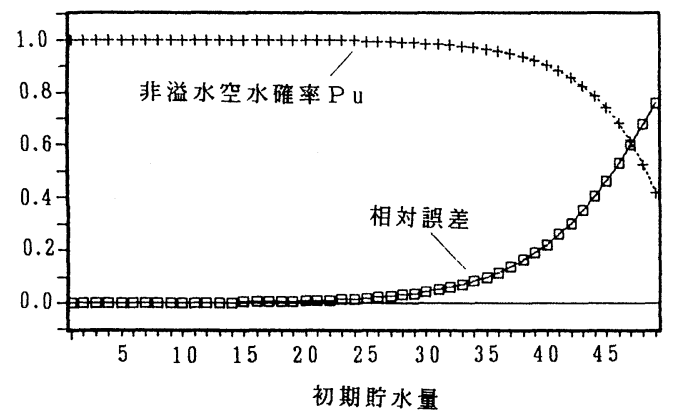

図一 12 段階推移法と Phatarfod 解による空水到達期待時 間の相対誤差と非溢水空水確率 $P_{u}$

$(K=50, \quad M=1, \quad r=2, a=0.4$, Corr. =0.6)

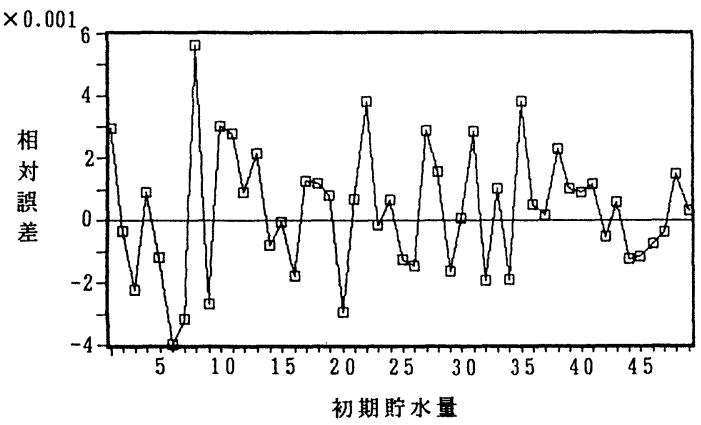

図一 2 数值実験解と 2 段階推移法による相対誤差 $(K=50, \quad M=1, \quad r=2, a=0.4, \quad$ Corr. $=0.6)$

るので溢水の可能性のある場合には Phatarfodの解は 使用すべきでない.

同じ条件で，今度は 2 段階推移法による解を真值とし て, 数值実験解との相対誤差を表わしたのが図一 2 であ る。これをみると，初期貯水量と相対誤差の間には何ら 関係がみられない。すすなわち，この誤差はただ単なる数 值実験上の偶発誤差だと思われる．また，その大きさは， 最大で $0.6 \%$ 以下であるから，このケースでは流量系列 の発生個数は上述の值で十分であろうし, 貯水量定常分 布の場合 ${ }^{1)}$ と同様に数值実験のような膨大な計算をしな くても，2段階推移法により簡単に時間的問題が取り扱 える.

なお, 同じ条件で, 数值実験解, 2 段階推移法, Phatarfod の解による空水到達期待時間を比較したのが図一 3 である. 数值実験解と 2 段階推移法は図一 2 からも推測 されるようにほとんど差がない。また，初期貯水量との 関係では，初期貯水量が大きくなるに従ってほぼ線形的 に空水到達期待時間が増す。 2 段階推移法と Phatarfod 解との比較では，図一 1 からも推測されるように初期貯 水量が満水量の $3 / 4$ くらいから Phatarfod 解が急速に 大きくなり， 2 段階推移法の 4 倍にもなる場合がある. したがって, 溢水の可能性のある場合には, 空水到達期

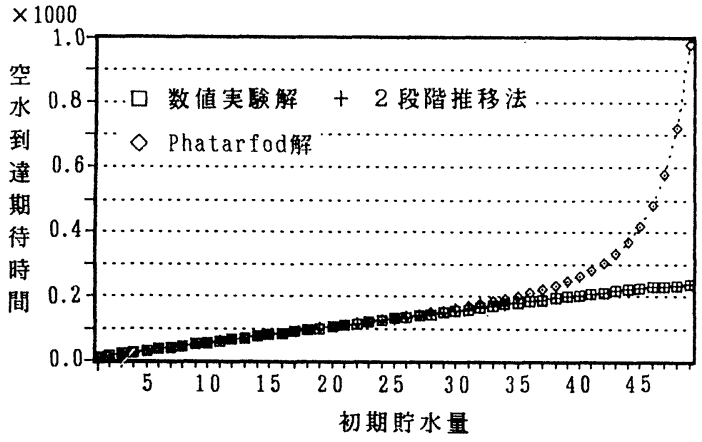

図一 3 各計算手法による空水到達期待時間 $(K=50, \quad M=1, \quad r=2, a=0.4$, Corr. $=0.6)$

待時間が初期貯水量と線形関係にある 2 段階推移法の採 用が妥当であろう.

\section{4 . 放流量系列問題}

\section{（1） 2 段階推移モデルによる放流量系列の導出}

2 .で述べた 2 段階推移モデルは貯水状態の推移に着 目したものであり，貯水状態の表現としては，放流量を 放流した後(つまり各期間の期首), の貯水状態を対象と していた，他方放流量を流す前（つまり期間の期末）の 貯水状態の推移を取り扱之ば, 期待放流量系列を求める ことができる.

各期間における放流量の期待值を求めるには，実放流 量 $R(i j)$ に対応する放流以前の貯水状態確率 $h_{j i 2}^{s}$ がわか ればよい.つまり $h_{j i 2}^{s}$ を要素とする行べクトル $\{H\}_{2}{ }_{2}$ の 推移を求めればよい。いま初期（期間番号 0 ）の期首の 貯水量ベクトル $\{H\}^{0}{ }_{1}$ が与えられると, 期間番号 0 の期 末の貯水状態確率ベクトル $\{H\}^{0}{ }_{2}$ は, 式 $(1)$ より次式で 表わされる。

$\{H\}_{2}^{0}=\{H\}^{0} \cdot G$

また，一般の期間 $s$ に対してはこの $\{H\}^{0}{ }_{2}$ を基礎として 式 (2)と式 (1)との合成によって,

$\{H\}^{s+1}=\{H\}_{2}^{s} \cdot \boldsymbol{R} \cdot \boldsymbol{G} \cdot$

となり，期間の期末の貯水状態確率ベクトルの推移が表 現できる.結局 $\{H\}^{s}{ }_{2}$ が求まればその要素 $h_{j i 2}^{s}$ を用いて, $s$ 期間における放流量の期待値 $E\left[R^{s}\right]$ は,

$$
E\left[R^{s}\right]=\sum_{j=0}^{n} \sum_{i=0}^{K} R(i j) \cdot h_{j i 2}^{s}
$$

で計算できる。

\section{5 . 利水安全度指標と利水機能評価関数}

\section{（1）代表的な利水安全度指標}

貯水池あるいは貯水池を含む利水システムの利水安全 度をどのような指標によって評価するかという問題は, 利水問題の基礎となる課題で, 中川 ${ }^{7)}$, Hashimoto $^{8)}$, 小 
尻・池淵9などいくつかの注目すべき研究がみられる。し かしながら, 各貯水池の地域的・社会的特性等がかなり 異なるために，一義的にどの指標がよいとはいいがたい ように思える。ここでは，建設省技術研究会により行わ れた研究成果を参考にして，上述の表現を用いた代表的 な利水安全度指標を記述する。

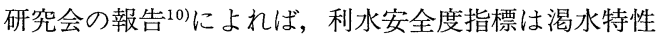
の面から以下の 4 つに分類される.

(1) 渴水の「頻度」を表わす指標

(2) 渴水の「長さ(期間)」を表わす指標

(3)渇水の「大きさ(程度)」を表わす指標

(4) 渇水の「厳しさ (深刻さ)」を表わす指標

すなわち，頻度を表わす代表的な指標として“渴水の 発生頻度” や貯水池での “補給不能発生日数” が，長さ を表わす代表的な指標として貯水池での “補給不能発生 日数”が，大きさを表わす代表的な指標として“不足％・ 日”が，厳しさを表わす代表的な指標として” (不足\%) 2 . 日”や“渇水被害関数”などが考えられている.

\section{（2）利水機能評価関数}

本研究では, 5.（1)の代表的な利水安全度指標にな らって「頻度」,「長さ」,「大きさ」,「厳しさ」の観点か ら貯水池の利水機能評価関数の表現を行う.

a ) 頻度を表わす評価関数

渇水の発生頻度を貯水量分布により評価する. 初期貯 水量べクトル $\{H\}^{0}{ }_{1}$ が与えられたとすると, 渴水期間 $N$ の最後の貯水量ベクトル $\{H\}^{N}{ }_{2}$ は,

$$
\{H\}^{N}=\{H\}^{0}{ }_{1} \cdot \boldsymbol{P}^{N} \cdot \boldsymbol{G} \quad(\boldsymbol{P} \equiv \boldsymbol{G} \cdot \boldsymbol{R}) \cdot
$$

で与えられる. 渇水の頻度は, 渇水期において放流量 $R$ が目標放流量 $M$ を下回る確率 (以後不足確率とよぶ) で 表現できるから, 貯水量べクトル $\{H\}^{N}{ }_{2}$ の要素 $h_{j i 2}^{N}$ を用 いて,

$$
\text { 不足確率 }=\sum_{j, i \in c} h_{j i 2}^{N}
$$

ここに, $C: R(i j)<M$ となる $i, j$ のすべての組合せ と表わされる。

\section{b）長さを表わす評価関数}

渴水期では，利水上危険な貯水量レベル（空水状態， あるいは最低限維持すべき貯水状態）に一度達したら， その後回復することは難しいと思われる，そこで，全渴 水期間 $N$ から貯水状態が危険なレベルに達するまでの 期待時間を差し引いた残りの期間を期待補給不能期間と 定義して渴水の長さの評価に用いる。いま筀水到達期待 時間を $E\left[t_{e}\right]$ とすれば,

期待補給不能期間 $=N-E\left[t_{e}\right]$

と表わされる。なお， $E\left[t_{e}\right]$ は，3.の空水到達時間で示 した手順で求められる。

\section{c）大きさを表わす評価関数}

渇水の大きさを不足 \%・期間の期待值で評価する。目 標放流量に対する相対不足\%は $((M-R(i j)) / M) \times 100$ であるから式(14)の期待放流量系列と同じ手順で，期待 不足\%・期間は，

$$
\begin{aligned}
\text { 期待不足 } \% \cdot \text { 期間 }= & \sum_{s=1}^{N} \sum_{j=0}^{n} \sum_{i=0}^{K}((M-R(i j)) / \\
& M) \cdot h_{j i 2}^{s} \times 100 \\
= & \sum_{s=1}^{N}\left(\left(M-E\left[R^{s}\right]\right) / M\right) \times 100
\end{aligned}
$$

で表わせる.

d）厳しさを表わす評価関数

渇水の厳しさを，各単位期間当たりの (期待不足\%) ${ }^{2}$ の全渇水期間にわたる総和で評価し，これを（期待不 足\% $)^{2} \cdot$ 期間と定義する. 各単位期間当たりの，目標放流 量に対する (期待不足\% $)^{2}$ は, 式(17) と同様に $\{((M$ $\left.-R(i j))(M) \cdot h_{j i 2}^{s} \times 100\right\}^{2}$ である.そこで全渴水期間にわ たり，これを総和して，

$$
\begin{aligned}
(\text { 期待不足 } \%)^{2}= & \sum_{s=1}^{N} \sum_{j=0}^{n} \sum_{i=0}^{K}\{((M-R(i j)) / \\
& \left.M) \cdot h_{j i 2}^{s} \times 100\right\}^{2} \\
= & \sum_{s=1}^{N}\left\{\left(\left(M-E\left[R^{s}\right]\right) / M\right) \times 100\right\}^{2}
\end{aligned}
$$

で求められる。この式は，一般的な意味の $(\text { 不足 \% })^{2} \cdot$ 期 間の期待值ではない. 貯水池の出力である放流量の期待 值 (放流量期待値)を基礎として用いた表現をしている. なお，煩雑となるので以後は，これを単に $(\text { 不足 \% })^{2} \cdot$ 期 間とよぶ.

\section{6. 貯水池操作方法の表現}

利水用貯水池の操作規則は, どういう貯水量や流量状 態の場合にどれだけ放流するかをあらかじめ策定してお くことといえる.

ここでは, 操作の単位期間は, 流量表現に関する時間 の離散化幅で表現する，もちろん一般に，離散化幅を細 かくすればきめ細かい操作に対応する.しかし, 細かい 分割はそれだけ流量分布の母数推定の精度の低下や計算 量の増大といった問題を伴う. また, 流入量分布に一次 の自己相関性を考慮しているから，引き続く期間での流 入量を予測する場合に，どの程度の離散化幅が精度のよ い予測を可能にするか, などといった問題にも注意を払 う必要がある.

さて，どういう状況でどれだけ流すかは，ここでは放 流量の設定として表現する。すなわち, 放流量を貯水状 態の関数とするか, 貯水状態と流入量の関数とするか, 
さらにどういった関数形とするかで，操作方針を表現す る.

\section{（1）貯水量方程式の拡張表現}

放流量 $R$ が貯水状態と流入量の関数であることを明 記するために，従来の貯水量方程式1を表現し直す。な お，ここでは，当該期間における完全な流量予測が不可 能で，放流を期末に一度に行う場合を対象とする。

従来の表記によれば， $s$ 期間の流入量 $Q^{s}$ を受けた期 末の貯水量状態 $Z^{s}{ }_{2}$ は， $s$ 期間の期首の貯水量状態 $Z^{s}{ }_{1}$ と $Q^{s}$ および有効貯水池容量 $K$ を使って, 次式のように 表現された。

$$
Z^{s}{ }_{2}=\min \left(Z^{s}{ }_{1}+Q^{s}, K\right)
$$

また，放流量を放流した後の貯水状態，つまり，S+1期 間の期首の貯水状態 $Z^{s+1}{ }_{1}$ は, 放流可能性を考之て, 次式 で表記された。

$$
Z^{s+1}{ }_{1}=Z^{s}{ }_{2}-\min \left(M, Z^{s}{ }_{1}+Q^{s}\right)
$$

したがって総合した貯水量状態の推移は式(19)，(20)よ $\eta$

$$
\begin{aligned}
Z^{s+1}= & \min \left(Z^{s}{ }_{1}+Q^{s}, K\right) \\
& -\min \left(M, Z^{s}{ }_{1}+Q^{s}\right)
\end{aligned}
$$

であった。なお，式(21)は，操作方針として「貯水状態 が目標放流量以上であれば目標放流量を，目標放流量未 満であれば目標放流量にできるだけ近い量を放流する」 という節水を考えない操作（以後無節水操作とよぶ）の 表現にほかならない，そこで，より一般性をもたせた操 作方法を考えるために，式(20)を次式のように拡張した 表記をする。

$$
Z^{s+1}{ }_{1}=Z^{s}{ }_{2}-R^{s}\left(Z^{s}{ }_{2}, Q^{s}\right)
$$

上式右辺の $R^{s}\left(Z^{s}{ }_{2}, Q^{s}\right)$ は $s$ 期間の放流量 $R^{s}$ が $Z^{s}{ }_{2}$ と $Q^{s}$ の関数であることを意味する。したがって式(20)は $R^{s}$ を以下のよjに設定したことになる。

$$
\begin{array}{ll}
R^{s}=M & \left(Z^{s}{ }_{2} \geqq M\right), \\
R^{s}=Z^{s}{ }_{2} & \left(Z^{s}{ }_{2}<M\right)
\end{array}
$$

以下では，この放流量関数 $R^{s}\left(Z^{s}{ }_{2}, Q^{s}\right)$ を使った操作方 法を表現する。

\section{7. 合理的放流操作の策定}

ここでは，渴水の厳しさの観点からみた放流操作を考 えよう。式(18)で表現した渴水の厳しさを表わす評価関 数である $(\text { 不足 \% })^{2}$ ・期間をできるだけ小さくするような 操作方法を合理的放流操作とみなすことにする.

\section{（1）確率 $\boldsymbol{D P}$ による最適放流量系列の導出}

無節水操作やその他の操作法との比較のために，渴水 の厳しさからみた最も理想的な最適放流量系列を確率 $D P^{11)}$ により求める。時間の流れを逆にとり，渇水期の最 後を $s=0$ とおくと, 貯水量方程式は,

$$
Z^{s-1}{ }_{1}=Z^{s}{ }_{1}+Q^{s}-R^{s}
$$

また，確率 $D P$ は，次式のように定式化できる.

$$
\begin{aligned}
& f_{s}\left(Z^{s}{ }_{1} \mid Q^{s}\right)=\min \left[D\left(R^{s}\right)\right. \\
& \left.\quad+\sum_{q=0}^{n} f_{s-1}\left(Z^{s-1}{ }_{1} \mid q\right) \times P\left[q \mid Q^{s}\right]\right] \\
& D\left(R^{s}\right)=\left(M-R^{s}\right)^{2} \quad\left(0 \leqq R^{s} \leqq M\right) \\
& f_{0}=0
\end{aligned}
$$

ここで, $\min は$,

$$
R^{s}+Z^{s-1}{ }_{1}=Z^{s}{ }_{1}+Q^{s}, \quad 0 \leqq Z^{s-1}{ }_{1} \leqq K
$$

を満たす各 $\left(R^{s}, Z^{s-1}{ }_{1}\right)$ の組合せの中での最小值を選ぶ ことを意味する．また，ここに $D(R)$ は不足量の二乗で 表現した渴水被害関数， $f(Z \mid Q)$ は $Q$ を既知とした場合 の $Z$ から生ずる $s$ 以後の総被害関数の最小値, $P[q \mid Q]$ は $Q$ を既知とした $q$ の条件付き確率である.

式(24)により，s=0から初めて, $s=N$ まで順次 $f_{s}$ を 求めれば，各初期貯水量に対応する最適放流量系列，お よび単位期間当たりの (不足\% $)^{2}$ の全渇水期にわたる和 の最小值が求められる.以後この操作を最適操作とよぶ.

\section{（2）評価の対象とする貯水池操作方法}

ところで前項の $D P$ による最適放流量系列は，（不 足\%) ・単位期間を最小にする操作ではあるが, 最後に貯 水量が使いきれるとしているし，また，操作法が時間に 依存した非定常操作であった。利水用貯水池では，非定 常操作は実用的とは思えないので, 以後では定常操作で, できるだけ $(\text { 不足\%) })^{2}$ ・単位期間を小さくするようなもの を式(22)の形式で表現する.

さて $(\text { 不足\% })^{2}$ ·単位期間を小さくすることは，最小二 乗誤差基準からみて，いわば，渴水期間中にわたり放流 量ができるだけ一定になるような操作に連なるものと考 えられる，ところで，いまの場合流量に自己相関性を勘 案していることから，当該期間の流入量から次の期間の 流入量の予測をし，流量が少ないときには少ない量を， 多いときには多い量を放流するような操作を考えてみよ j.

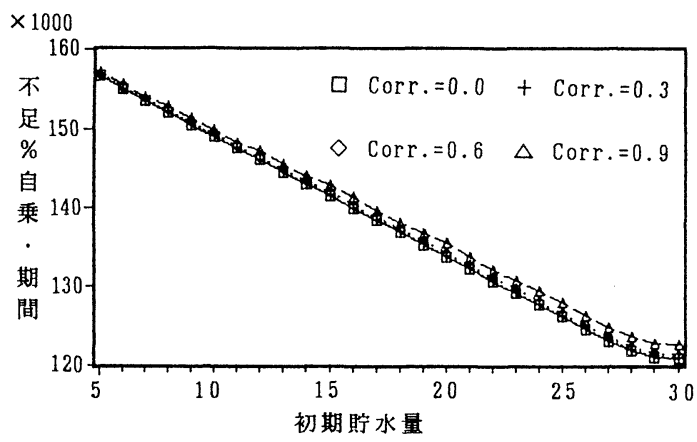

図一4 相関係数の違いによる $(\text { 不足 \% })^{2}$ ・期間の比較 (無節水操作) $(K=30, M=5, N=30, r=5, a=0.3)$ 


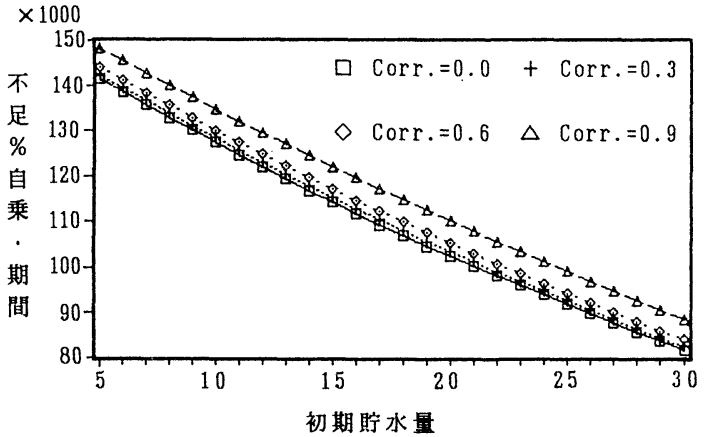

図一 5 相関係数の違いによる $(\text { 不足 } \%)^{2} \cdot$ 期間の比較

(最適操作) $(K=30, \quad M=5, \quad N=30, \quad r=5, \quad a=0.3)$

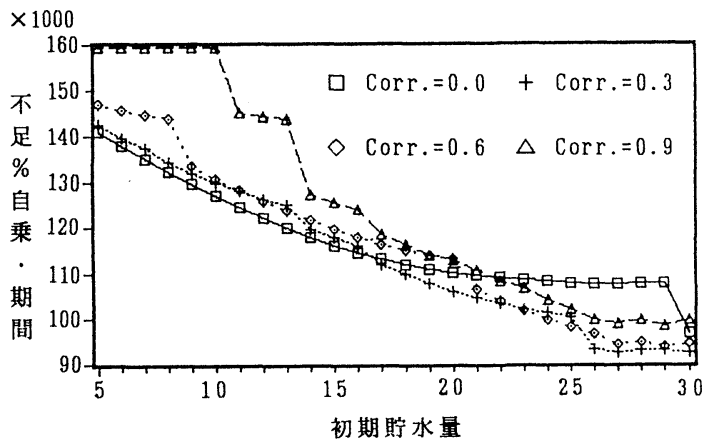

図一 6 相関係数の違いによる (不足\% $)^{2}$ ・期間の比較

(予測操作) $(K=30, \quad M=5, N=30, \quad r=5, \quad a=0.3)$

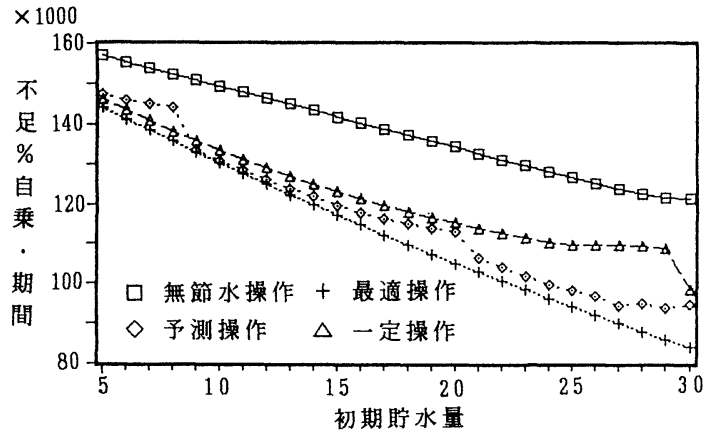

図一7 操作方法による (不足\%) ${ }^{2}$ ・期間の比較

$(K=30, M=5, N=30, r=5, a=0.3$, Corr.=0.6)

いま, 流入量平均を $Q_{m}$, 流入量の自己相関係数を $\rho$ と すると, $s$ 期間の流入量 $Q^{s}$ が既知の場合，採用してきた 相関分布では, $s+1$ 期間の流入量 $Q^{s+1}$ の条件付き期待 值は，次式の線形回帰で表わされることが知られてい る $^{12)}$.

$$
E\left[Q^{s+1} \mid Q^{s}\right]=(1-\rho) \times Q_{m}+\rho \times Q^{s}
$$

そこで， $s$ 期間の放流量 $R^{s}$ は, 初期貯水量による放流分 と, $Q^{s+1}$ の期待值による放流分とを加算して, 次式のよ

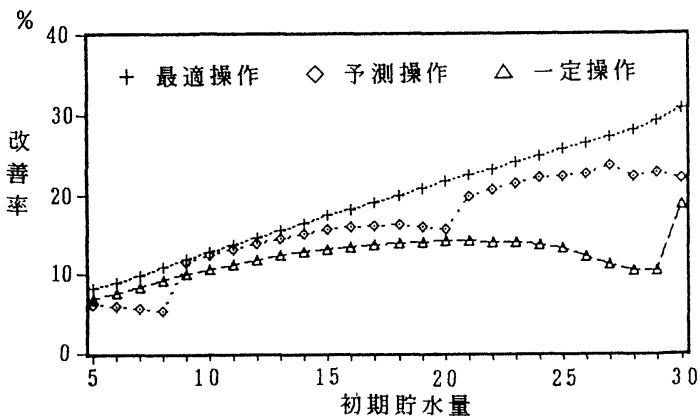

図一 8 操作方法による改善率の比較

$(K=30, M=5, N=30, r=5, a=0.3$, Corr. $=0.6)$

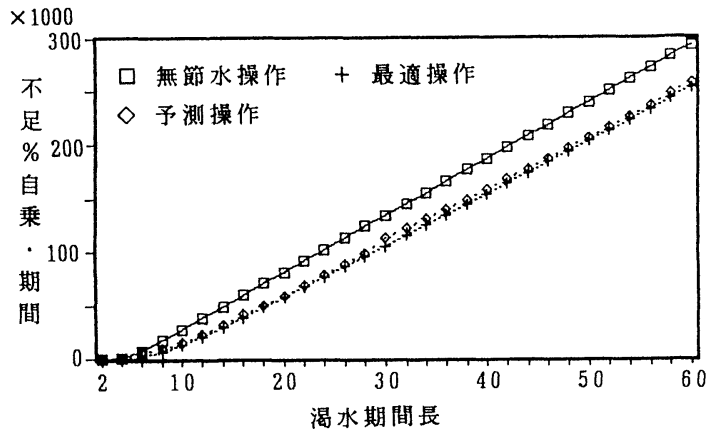

図一9操作方法による (不足\% $)^{2}$ ・期間の比較 $(K=30, M=5, U=20, r=5, a=0.3$, Corr. $=0.6)$

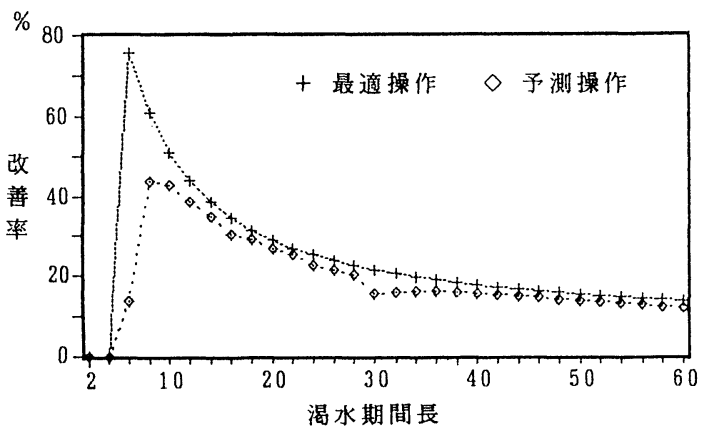

図-10 渇水期間長と改善率

$(K=30, M=5, \quad U=20, r=5, a=0.3$, Corr. $=0.6)$

うな関数で表現する.

$$
\begin{aligned}
& R(i j)=M \quad\left[M \leqq U / N+(1-\rho) \times Q_{m}+\rho \times j \leqq K\right] \\
& R(i j)=(U / N)+(1-\rho) \times Q_{m}+\rho \times j \\
& \quad\left[U / N+(1-\rho) \times Q_{m}+\rho \times j \leqq i<M\right] \\
& R(i j)=i \\
& \quad\left[0 \leqq i<U / N+(1-\rho) \times Q_{m}+\rho \times j\right]
\end{aligned}
$$

上式で $U$ は初期貯水量を意味する.なお, $R$ は離散化量 なので，上式で求めた数值を，四捨五入して整数化して 
用いる. 以後この操作を予測操作とよぶ.

\section{8. 適用計算例}

有効貯水池容量 $K=50$, 目標放流量 $M=5$, 渇水期間 長 $N=30$ の条件で, 上限 $r=5$, 形状母数 $a=0.3$, 相関 係数 $\rho=0.0 ， 0.3 ， 0.6 ， 0.9$ の相関二項分布流量を与之た ときの $(\text { 不足 } \%)^{2} \cdot$ 単位期間と初期貯水量との関係を図 $-4 \sim 6$ に示す. 図一 4 は無節水操作, 図一 5 は確率 $D P$ による最適操作, 図一 6 は, 式(26)に示した予測操作の 場合である．まず無節水操作と最適操作は，值そのもの は最適操作の方が小さいという違いはあるが，全体的な 傾向は類似している.つまり, 相関の大小にかかわらず, $(\text { 不足 } \%)^{2}$ ・単位期間と初期貯水量の間では，初期貯水量 が増加するほど $(\text { 不足\% })^{2}$ ・単位期間が線形的に減少す る。ただし，無節水操作に打いて，初期貯水量が満水に 近くなると，ややその関係が不明確となる。これは，ま だ貯水量が満水に近い渴水期初期に，大きな流入量が生 起すると，目標放流量以上の放流をして，溢水（つまり 無効放流）をしてしまう場合があるためと思われる，さ らに相関係数の影響をみると，相関が強いほど，(不 足\%) ${ }^{2}$ 単位期間が大きくなっている。この理由として, 流入量分布に，量の少ない方にひずんだ（正のひずみを もつ）分布形を与えているため，自己相関が強くなるほ ど，量の少ない範囲の持続性が強く働き，渴水傾向が強 くなるためであろう。

他方予測操作の場合 (不足\% $)^{2}$. 単位期間と初期貯水量 との間には，初期貯水量が多くなれば $($ 不足\%) 2 ·単位期 間は減少するという関係は認められるが，その変化の仕 方は不連続で，全体でみると線形関係とはみえない．ま た，その傾向は相関が強いほど，強くなる．これは，式 (26)の放流量の関数值が整数化されることにより, 所与 の初期貯水量などの貯水池条件に対して予測操作による 効果が不明膫になるためであろう。さらに相関係数が大 きいほど流入量が放流量に与える影響が大きくなり，不 明瞭になりやすいものと思われる。

次に, 先と同じ貯水池条件で, $r=5, a=0.3, \rho=0.6$ の 相関二項分布流量を与えたときの, 無節水操作, 最適操 作，予測操作，および式(26)で $\rho=0$ ，すなわち流入量の 影響を受けないとした場合（以後一定操作とよぶ）の 4 ケースについて $\left(\right.$ 不足\%) ${ }^{2}$ 単位期間と初期貯水量との関 係を図一 7 に示す．また無節水操作の場合からどれだけ $(\text { 不足\% })^{2}$ ・単位期間が減少 (改善)したかを無節水操作に よる $(\text { 不足\% })^{2}$ ・単位期間を 100 とした場合の減少百分率 (改善率)として図一 8 に示す. 圀一 7 によると，予測操 作はかなり最適操作に近く，有効な操作であることがわ かる．また，ほとんどの場合，予測操作の方が，一定操 作より $(\text { 不足 } \%)^{2}$ ・単位期間が小さいので，放流量を決め
る際に流入量を情報として用いた方がより合理的なこと がわかる．改善率は，全体的な傾向として，どの操作の 場合も初期貯水量が大きくなるほど上がっている。した がって,まだ渇水が深刻でなく貯水量に余裕のあるほど, 利水効果が期待できることとなる.

図一 7，8 と同じ条件で, 初期貯水量を 20 単位とし, 渴水期間長と $(\text { 不足 } \%)^{2} \cdot$ 単位期間との関係を図一 9 に, 渴水期間長と改善率との関係を図一10に示す.やはり， 予測操作は，最適操作にかなり近い值を示す．全体的な 傾向としては，渇水期間が長くなるほど，(不足\%) $)^{2}$ 単 位期間も大きくなり，その関係はほぼ線形的になる。改 善率は, 渴水期間長が長くなるほど小さくなっており, やはり渴水傾向が弱いほど予測操作の効果があるようで ある。

\section{9.まと め}

得られた成果を箇条書にして以下に示す。

（1） 2 段階推移モデルが，空水到達期待時間などの 利水機能の時間的な側面の評価に有用なことを示した。

（2） 2 段階推移法, 数值実験, Phatarfod の解の各方 法により空水到達期待時間を求め, 比較した結果， 2 段 階推移法の妥当性と, Phatarfod の解の適用の限界を示 した.

（3） 2 段階推移モデルにより，実用的な利水安全度 指標に対応する利水機能評価関数を計算できることを示 した.

（4）渴水の厳しさの観点から, 確率 $D P$ による最適 操作，流入量を情報とした予測操作，可能な限り目標放 流量を放流する無節水放流の 3 つの操作方法を評価した 結果, 予測操作が, 最適操作とほぼ同等に合理的な操作 であることがわかった。

\section{0.あとがき}

現実の利水安全度に対応した評価関数という観点か ら，本稿ではいくつかの機能評価関数を設定し，そのう ち渴水の厳しさを表わ寸評価関数について適用計算例を 提示した。 しかしながら本来, 貯水池に求められる利水 機能は，その貯水池系に特有なさまざまな自然的・社会 的・経済的条件などにより異なるはずであり，一般にど の評価方法がよいとは断定できない。ここに示した評価 関数のみならず，より基礎的な貯水量定常分布，空水到 達期待時間などをもとに，それぞれの貯水池系に適した 評価関数を設定し，利水評価を実施していくべきである ことはいうまでもない，しかし，その際に本研究で提案 した 2 段階推移法による時間的側面の勘案は，いずれに おいても基礎とした役割を果たし得るものと期待してい る。また，本稿では，計算例として，仮想の貯水池条件， 
流入量分布を設定して，利水機能評価を行った，実存す る貯水池への適用に際しては, 流入量の確率特性の定常 性が保証されるように季節分割を行い，各季節に応じた 目標放流量を設定して, 各季節ごとに利水機能評価を行 うことで，流入量，目標放流量の季節変化に対応できる と思われる。

\section{参 考 文 献}

1）鈴木正人・長尾正志：2 段階推移モデルによる相関離散 分布流量を受ける貯水池理論，土木学会論文集，第 411 号 / II-12, pp. 161 168, 1989.

2) Moran, P.A.P.: A probability theory of dams and storage systems, Aust. J. Appl. Sci., Vol. 5, pp. 116 $\sim 124,1954$.

3）長尾正志・梶間津洋志：利水用貯水池における期間長特 性の確率行列による推算, 第 24 回水理講演会論文集, pp. 65 70, 1980.

4）森村英典・高橋幸雄：マルコフ解析, 日科技連, pp. $60 \sim 66,1979$.

5) Phatarfod, R.M. and Mardia, K.V.: Some results for dams with Markovian inputs, J. Appl. Prob., Vol. 10, pp. 166〜180, 1973.

6）長尾正志：貯水池による水量制御の信頼性評価，土木学 会水理委員会水工学シリーズ, 84-A-1，1984.

7）中川芳一：水資源システムの策定プロセスに関する一考 察, NSC 研究年報, Vol. 8, No. 1, pp. 21 67, 1980.

8) Hashimoto, T. et al.: Reliability, Resiliency, and Vulnerability Criteria For Water Resource System Performance Evaluation, Water Resources Research, Vol. 18, No. 1, pp. 14 20, 1982.

9）小尻利治・池淵周一・飯島 健 : 安全度評価をべースに した最適な水利用システムの構成, 第 29 回水理講演会論 文集，pp. 323 328，1985.

10）建設省河川局河川計画課 - 建設省土木研究所：利水安全 度に関する研究, 第 36 回建設省技術研究会, pp. 73〜 79, 1982.

11）たとえば, 吉川和広ら：土木計画学演習, 森北出版, pp. 139 144, 1985.

12) Edwards, C.B. and Gurland, J. : A class of distributions applicable to accidents, Journ. Amer. Statist. Ass., Vol. 56, pp. 503 517, 1961.

(1989.12.4 • 受付) 